\title{
9
}

\section{AERIAL STAR}

Lillian Leitzel's celebrity, agency and her performed femininity

\author{
Kate Holmes
}

Circus was one of the largest mass live entertainments of the early twentieth century and was an industry that secured its popularity through a number of female stars. These women's careers were not only established by the highest-profile circuses but also contributed to their success. Although circus has been the focus of numerous memoirs or popular histories, few recent layered historical analyses of this complex entertainment form exist. As such, the female performers who played such an important part in its mass popularity have largely faded from view. ${ }^{1}$ In this chapter I explore and evaluate the work of the pre-eminent circus celebrity of the early twentieth century, Lillian Leitzel (1892-1931). Circus stars were household names who entertained international audiences, and as an aerialist Leitzel excelled in one of the two most popular disciplines in the circus, the other being equestrianism. As an industry, circus has always capitalised on women's labour, placing them in prominent positions, whether as members of troupes or as soloists, but in the $1920 \mathrm{~s}$ female soloists featured in a number of international circuses as their highest-profile stars. These solo aerialists were distinguished from their colleagues within mixed gender troupes because they performed independent feats of bodily control, at a time when women were claiming a more active role for themselves more generally. While stage representations of women and the flesh they exposed were constrained by censorship, ${ }^{2}$ female solo aerialists' performances were predicated on openly demonstrating their physical capability and their physical freedom.

The 1920 s was a particularly interesting time in circus history in the USA and England because of the popularity of circus and changes in the industry. In America, the Ringling Bros and Barnum \& Bailey Combined Show was touring the country with a Big Top tent capable 
of holding over 16,500 audience members for twice-daily performances. The American Big Top may have reached its peak capacity in the 1920 s (Dahlinger Jr, 2008: 224; Davis, 2002: 293), but this was not to last, as the economic downturn that created the American Depression in the early 1930 s would become a key factor in the demise of huge tenting circuses - those that display under canvas. By contrast, UK circus was entering a period of reinvigoration that continued until the 1960s, spearheaded by Bertram Mills Circus. Temporarily occupying London Olympia, this most significant of British 1920 s circuses was capable of finding audiences of approximately 6,000 people, again twice daily during a Christmas season. ${ }^{3}$ The most popular UK and American circuses were therefore large-scale enterprises that entertained mass audiences. Performers who appeared in circuses owned by Ringling and Mills benefited from significant levels of publicity and exposure that was central to the fashioning of their public images. This enabled the most popular performers to gain year-round employment by using the prestige gained in circus to secure seasonal and short-term contracts in related professional contexts: entertainments such as American vaudeville and European variety during the circus off-seasons. The interwar period was significant not just in terms of the popularity of circus, but also because it was arguably the last era when circus celebrities could globally draw upon such powerfully coordinated circus publicity to inspire the popular imagination.

\section{'Queen of the Circus'}

Perhaps the most surprising early twentieth-century circus star to have been forgotten by all but the most informed circus fans is the solo aerialist Lillian Leitzel, who earned the title 'Queen of the Circus' ${ }^{4}$ From 1915 until her death in 1931 Leitzel secured bookings with the most prestigious American circuses owned by the Ringling family. ${ }^{5}$ Born Leopoldina Alitza Pelikan in Breslau, Germany in 1892, she used the German and Bohemian childlike diminutive of Alice, 'Leitzel', as her solo stage surname. ${ }^{6}$ The choice of surname points to a facet of her performance style that combined dainty and girlish appearance with a modern assertive expression of femininity that included sexual agency. Throughout the 1920s Leitzel performed annually in America's largest circus, Ringling Bros and Barnum \& Bailey Combined Show, as its premier performer. This engagement formed the spine around which she, and other premier Ringling-Barnum performers, secured international contracts 
that ensured continuous employment throughout the year. During her lifetime she gained preferential treatment from Ringling management backstage as well as in press and publicity, where her image and name were used heavily. She had a special clause in her contracts that secured her space, privacy and comfort when travelling across America with the circus, while her image was reproduced in souvenir programmes more frequently than that of any other performer. ${ }^{7}$ Leitzel died at the height of her popularity as a result of an injury sustained in performance on 13 February $1931 .^{8}$ While her death gave her star image a notoriety that ensured that she is still remembered by some circus fans today, she was undoubtedly the most prominent circus artist of the 1920 .

What is particularly interesting about this diminutive performer is that her stardom derived from an endurance act that required considerable strength, at a time when demonstrations of female strength might conventionally be considered remarkable. Leitzel was among the first aerial stars to be heavily promoted for her endurance and athleticism at a time when sport and sports participation was becoming popular. What set her apart from her fellow female aerialists was her expert showmanship, which relied on a complex performance of femininity and balanced risk with skill to create the pleasurable frisson of excitement for audience members. ${ }^{9}$ In this chapter, I focus on her expert performance of gender, because she challenged both nineteenth- and emerging early twentieth-century stereotypes of femininity, while gaining widespread popularity across the mainstream entertainments of circus, American vaudeville and European variety. Circus memoirs often centre her popularity on her crowd-pleasing feat of endurance - one that simultaneously emphasised her weightlessness and strength - but it was Leitzel's almost contradictory performance of her gender that was responsible for her success. Her star image is fascinating because not only did it represent her as the 'Queen' within the circus, but her international engagements were predicated on publicly presenting her as having control over her professional career.

\section{Public autonomy}

The pattern of engagements that female performers secured had significance for the fashioning of their public images. The largest circuses in both America and England were run by male impresarios: John and Charles Ringling (up until the latter's death in 1926) and Bertram Wagstaff Mills. Both chose to use marketing strategies that linked their 
identities to their circus and made them celebrities. The appearance of John Ringling at a European or American circus indicated that he was scouting for performers (North and Hatch, 2008: 122), while Bertram Mills Circus is said to have obtained its reputation from the fact that a member of the Mills family had personally vetted every act (Williamson, 1938: 10). On both sides of the Atlantic, these prestigious circuses were represented as deriving their quality standards from the personal curation of either John Ringling or Bertram Mills (and sons). The visible relationship between the male impresario's professional identity and the circus provides a wider structure through which female soloists' performances must be read. The very mobility that performers demonstrated by appearing across a range of international venue types complicates the manner in which female soloists were represented in male-managed circuses.

Leitzel's visible mobility confuses the subordinate relationship of the female performer to the male impresario, because audiences were not restricted to viewing their empowered acts of female strength in just the circus venue, but could also enjoy them in variety and vaudeville venues - the most illustrious of which were the London Palladium or the Palace in New York. Although these permanent venues were also managed by men, it is the fact that female acts appeared across such venues and across international locations that allows the perception that the most popular performers had some autonomy over their own careers: they were demonstrating their choice over where and when they performed.

Questions of female agency within male-managed entertainments are further complicated when the female star's celebrity is significant enough to claim a different or dominant position for her professional identity, as was the case for Lillian Leitzel. Leitzel may have been most closely associated with the Ringling Bros and Barnum \& Bailey Combined Show because she appeared annually with them, and played only a single season with Bertram Mills Circus; however, there is a similarity in how Leitzel was depicted on both sides of the Atlantic. At Olympia in January 1922 the business manager Captain Pickering presented Bertram Mills with 'an illuminated address ... And a gold mounted, inscribed reading glass, and Miss LILLIAN LEITZEL, on behalf of the artists, presented Mrs Mills with a bouquet of mauve and pink tulips. ${ }^{10}$ This was probably a role she had been performing for the Ringling-Barnum circus in America for some time. Pasted into American circus fan Lorabel Laughlin Richardson's scrapbook is a cutting that describes an occasion when the Iowa Circus Fans Association hosted the Ringling-Barnum 
'circus performers and executives'. ${ }^{11}$ What is particularly interesting is that the scrapbook clipping outlines all of the individuals who spoke at the event. The article lists the representatives of the Circus Fans Association before the three members of Ringling staff who spoke at the event: John Ringling, Fred Bradna (Equestrian Director) and Lillian Leitzel. Here Leitzel's role as premier artist puts her in the position of performer-spokesperson with a public status that places her alongside the circus owner and management. In both situations it is Leitzel's job to speak or act on behalf of the performers alongside their management. Her celebrity status as 'Queen of the Circus' positioned her as more than simply a hired performer. Unlike film stars, she was not shackled to a particular studio system in a particular country. In professional terms, Leitzel's pre-eminent international popularity meant that she could publicly demonstrate both her star status and her mastery over her own career.

Despite being the most successful circus celebrity of her generation, as evidenced in her roles as performer representative, the primary sources left to enable us to reconstruct and describe Leitzel's act are fragmentary. This is partly because circus programmes were so packed that to provide full coverage of every act would have required unreasonably long newspaper reports, but more significantly perhaps, it is due to the difficulty of describing such embodied practices with language alone. In reconstructing Leitzel's performances, her extraordinary popularity has at least meant that snatches of publicity and press reports, photographs, costumes, film and memoir have survived to describe elements of her act. Although fragmentary, these sources can be used to historically reimagine her act with the benefit, here, of my own embodied experience as an amateur aerialist.

\section{A remarkable act}

Flanked by a maid and footman, Leitzel enters the tent to begin the first section of her act, described by memoir writers as an 'exquisite gymnastic turn' in which Leitzel demonstrated her 'artistry' (Pond, 1948: 124; North and Hatch, 2008: 184; Manning-Sanders, 1952: 242). As the circus band plays 'The Crimson Petal' waltz by Fred A. Jewell, which became closely associated with her act (Studwell et al., 1999: 9), she takes premier position centre ring. At less than five feet tall she appears small in comparison to her six-foot-tall footman. Her petite stature combined with her short frilled dress makes her appear dainty and exposes her body 

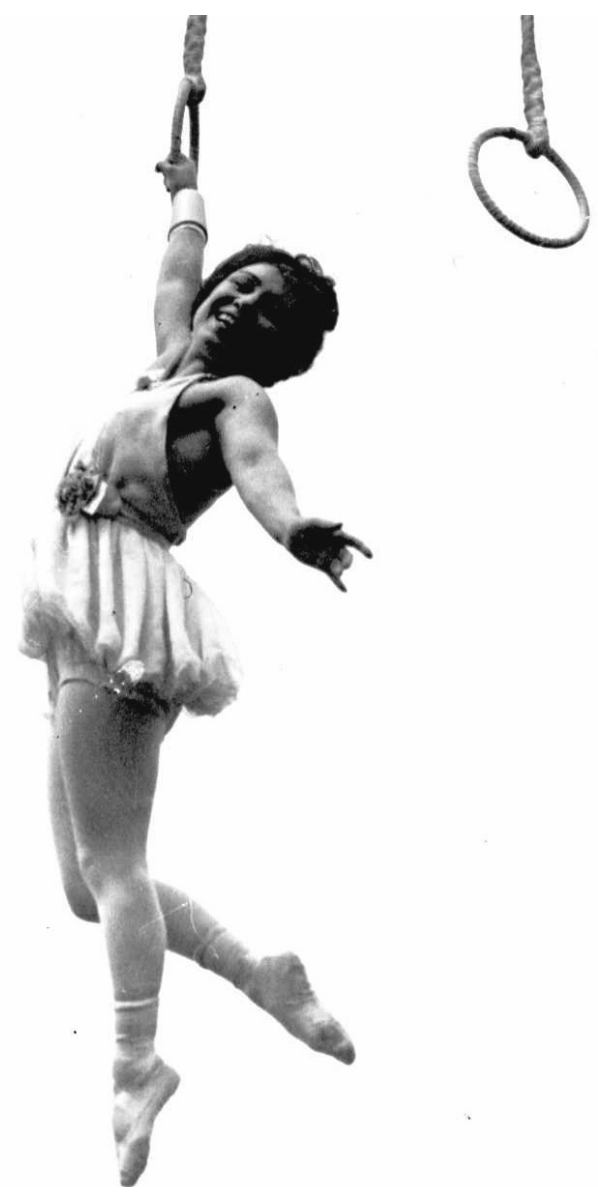

28 Photograph of Lillian Leitzel hanging from Roman rings, 1925, edit of CWi 873 glass plate negative. Circus World Museum, Baraboo, WI, Harry Atwell.

- opening it up to a desiring gaze (Kline, 2008: 60-1; Bradna and Spence, 1953: 148). Her maid and footman assist her in removing the cloak or long transparent train that covers her shoulders, while she kicks off the high-heeled mules that protect her performance shoes from the ring (Bradna and Spence, 1953: 149; Taylor, 1956: 221). ${ }^{12}$ Reaching for the rope, she flicks it seductively, holding it high with one hand and throwing the tail with the other to display her moving body. Leitzel then reaches high 
to grip the rope and pull her body up, curving her back over her hand. Reaching higher again, she kicks up and curves her body over again, propelling herself upwards. She continues to use this climbing technique, more usually associated with male performers due to the strength it required (Croft-Cooke and Meadmore, 1946: 65; Bradna and Spence, 1953: 149), until she reaches her Roman rings. Here she blows kisses to the crowd before reaching across to the first ring and then the second, until she is grasping both (O'Brien, 1959: 124). ${ }^{13}$

Hanging from her rings she begins the first main section of her act in earnest, using a combination of momentum, strength and deliberately graceful poses. She kicks her legs up and hooks them into the rings, pulling herself up to sit and look out at her audience. She hangs from one ring, kicking her feet up and curving her back over her hanging arm, stretching the free arm over her head to assist her balance. Pausing for a second she releases her body, letting it fall downwards before using the momentum at the bottom of the swing to kick up again - simultaneously appearing weightless while hinting at the strength required. The movements fit with the rise and fall of the waltz's music and rhythm. Hanging by one ring she extends one leg and points the other in a position reminiscent of the retiré in ballet, using momentum to spin her body and the swivel rigged into the equipment (Figure 28). Grasping both rings, she kicks her legs back and forth to propel her body over her head. She first performs a handstand made more difficult by the instability of using the rings as a base. She adds embellishment to her muscular control by kicking her feet together as she holds her body, inverted and parallel - obscuring the effort through this elaborately feminised display. Sometimes she drops from this position to begin her revolutions between her shoulders, and at other times she kicks her legs back and forth, driving her legs over her head to create the required momentum. Moving from her rings she reaches for her rope. Gripping it under her armpit she reaches downwards for the rope, gripping and releasing so that she appears to spin towards the earth until her toes reach the ground. ${ }^{14}$

The crowd wait expectantly as they anticipate the endurance feat that is said to have made her famous and that is at times denigrated by memoir writers as crowd-pleasing or 'common stunting' (Manning-Sanders, 1952: 242; North and Hatch, 2008: 184). While her maid arranges her hair and clothing and Leitzel pauses to look at the audience, the announcer frames her act, emphasising the 'test of endurance' (Pond, 1948: 124) and concluding with 'Miss Lillian Leitzel, the only living person to perform this feat!' (Kline, 2008: 209). As he finishes speaking she slips her wrist 
into the loop at the bottom of the planche rope required to perform her spectacular finale and swiftly travels upwards with elegantly pointed toes as property men haul on the free end of the rope. ${ }^{15}$ As the pulley hits the plunger her body jerks and she begins to kick and scissor her feet back and forth. Simultaneously she pushes down on the rope, pushes her hips upwards and her head back, to begin the first planche turn revolution of her body around her wrist. ${ }^{16}$

For this finale the musical accompaniment changed to emphasise the spectacular nature of each turn. Towards the beginning of her career her planche turns were accompanied by Rimsky-Korsakov's The Flight of the Bumblebee, which added a sense of frenetic tension to the performance. From around 1925 this changed to a special arrangement by Ringling Bros and Barnum \& Bailey bandmaster Merle Evans to the staccato 'The Dance of the Hours' from La Gioconda by Amilcare Ponchinelli (Bradna and Spence, 1953: 150). Heightening anticipation further, each revolution is accompanied by a strike of the bass drum and the announcer who encourages the audience to join together in counting Leitzel's progress through a movement that is far from smooth (O'Brien, 1959: 125). Her body slows as her head comes underneath it and her legs reach the apex at the top of the swing, forcing the rope to jerk. This jerkiness, in combination with continuous revolutions, is perhaps what led some to describe Leitzel's planche turns as 'violent' while also making her body 'whirl' (Taylor, 1956: 220). ${ }^{17}$ Yet what is most engaging about her performance is the wide smile that accompanies a body that appears subject to jerky movements while whirling weightlessly free. ${ }^{18}$

One or two of these revolutions around the wrist would be considered extraordinary, but Leitzel performed around one hundred towards the beginning and sixty towards the end of her career, twice daily. The feat requires considerable core, arm and shoulder strength alongside the engagement of leg muscles. Part of the excitement of watching Leitzel derived from seeing how many of these planche turns she could or would perform in that particular performance. As she progressed through her many revolutions, the force of her movement was emphasised as her hair slowly unravelled and whirled with her body (Bradna and Spence, 1953: 150; Taylor, 1956: 220). Once she had completed her revolutions, the property men released her to the ground, slowing as she reached the earth so that her elegantly pointed toes could skim the sawdust before she alighted. Her choice to slowly alight, rather than speed towards the ground with force, diminished the apparent risk she demonstrated to audiences while it self-consciously emphasised her balletic appearance. 


\section{Performing femininity}

Although much of the act itself might appear remarkable for its aerial virtuosity, what strongly emerges is Leitzel's complicated performance of her muscular acts within the frame of the 'feminine'. While the performance incorporates traditional markers of femininity, it is also built around the display of strength and an assertive modern expression. For Leitzel: 'Strength is not a matter of sex [...] It is purely a matter of power [...] It is a matter of nerves and muscles, irrespective of whether you are masculine or feminine. ${ }^{19}$ Such a statement indicates that Leitzel was aware of how she performed and of how she might negotiate gender.

What makes her performance of femininity particularly significant is that she was performing in the context of changing stereotypes of femininity. The 1920s was often presented in the popular press and through advertising as the era of the 'modern girl', known as the flapper in the UK and USA, but by the terms garçonnes, moga, modeng, xiaojie, schoolgirls, kallege ladki, vamps and neue Frauen in other national contexts (Barlow et al., 2005: 245). This remarkably widespread phenomenon extended, Søland suggests, 'across class lines, post-war female youths did in fact seem to understand and define themselves as a generation' (Søland, 2000: 13). The assertive modern girl was an evocative icon of the period who claimed a different femininity for herself across global and class boundaries - even if the precise expression varied according to these parameters (Søland, 2000: 17; Barlow et al., 2005; Kingsley Kent, 2009: 39-40; Melman, 1988). Examining Leitzel's performance of femininity in light of the idea of the 'modern girl' reveals striking similarities, but also differences that point to Leitzel's act pushing beyond the boundaries of this challenging new popular stereotype of modern femininity. Her performed femininity incorporated both older and modern expressions, allowing a radically muscular representation of femininity to appear within the mainstream.

Film stars such as Clara Bow and Louise Brooks epitomised the modern girl stereotype, embodying fun, physical activity and agency. These women speed, for example, through narratives that 'concern the flapper's pursuit of modern life - independent from parental and other authoritarian control - and a modern romance in which her defiant actions, unruly behavior, and daring dress are either obstacles or catalysts, or both' (Landay, 2002: 224). They have a role in defining their own futures, which to some extent reflects their status as being the first generation of women to have easier access to an independent income 
because of expanding work opportunities (Søland, 2000: 6; Kingsley Kent, 2009: 152). Wearing the latest fashions, they are frequently filmed laughing and enjoying themselves in energetic activities such as dancing. The active personas they present take advantage of one of the film star's biggest assets, the eyes, to challenge any simple designation of the film star as objectified. Lori Landay argues that their eyes demonstrate the ludic potential of comedy to disrupt objectification and, in Clara Bow's case, a powerful 'desiring female gaze that is so active we can see it reach across the frame' (Landay, 2002: 240). Not every woman would be prepared to risk the danger of being associated with such an uninhibited expression of the active modern girl as demonstrated by film stars, but many did aspire to this stereotype, self-fashioning an expression of it that made them feel 'modern'.

Although the modern girl was fashionable, her femininity was problematic for the older generation. Susan Kingsley Kent paints an evocative description of the 'problem':

\begin{abstract}
young women of virtually every class - called, derisively, 'flappers' dressed in boyish fashions, cut their hair short, smoked cigarettes, drove cars, and generally pursued an active, adventurous lifestyle [...] Boyish women and effeminate men dominated the fashion pages of newspapers and magazines, representing the carefree, youth-orientated, pleasureseeking, even hedonistic nature of the post-war generation sick and tired of a devastating war to which they had been unable to make a contribution; for others they constituted proof that society was in a complete state of disorder - disorder represented in gendered and sexualized terms. (Kingsley Kent, 2009: 39-40)
\end{abstract}

In striking contrast to the Victorian ideal of the 'Angel in the House' representing the attributes of submissiveness, passivity or devotion to the men in their lives - these women were assertively claiming their right to enjoyment on whatever terms they could. This enjoyment included control over their own physically active bodies, with participation in exercise figuring as an essential part of women's engagement in modernity and the ideal of a fun-loving, vibrant modern girl (Søland, 2000: 48; Skillen, 2012: 752; Zweiniger-Bargielowska, 2011; Skillen, 2013). Fashions associated with this stereotype also hinted at an interest in sex through the exposure of arms and legs. These modern girls symbolised the proposition that a host of young women were beginning to take more control of their own lives than they ever had before.

Analysing Leitzel's performance in the context of such changing attitudes to femininity provides answers to some of the apparently 
contradictory expressions of femininity that appear within her act. There are plenty of examples of her assertiveness in returning the audience's gaze and demonstrating bodily control, but there are also examples of her drawing upon older ideals. Leitzel cleverly included enough conservative allusions within her expressions of femininity to be popular in the mainstream, while pushing at the boundaries of being acceptably modern.

Although what Leitzel was doing was a particularly complex performance of femininity, it should be noted that aerial performance as a form also suggests the sort of gender blurring that was causing some levels of social anxiety. This is because aerial action relies on both grace and strength, traditionally attributed as feminine and masculine respectively. The description of Leitzel's act above highlights the strength required to perform the planche turns and her handstand in the rings, but all aerial action requires the upper body to hold, push or pull the body into position. However, aerial movements do not just rely on strength, they are also made easier through the use of good technique that appears graceful by requiring tensed, extended and elongated muscles and the use of momentum created by movement. This has led Peta Tait to describe the aerialist's body as where 'double-gendering' occurs (Tait, 2005: 31). The combination of strength and movements that suggest extension contribute to aerial action appearing weightlessly graceful. Against the context of anxiety around blurring the boundaries of the sexes in both the USA and UK in the 1920s, this combination was instead a negotiation of gender that is, most usefully, seen as part of the wider cultural 'reframing' of femininity.

The relationship between grace and femininity in the 1920 s is an interesting one because it evoked both modern and conservative femininity. Ballet is traditionally considered both graceful and feminine, primarily because technique gives the impression of 'weightless femininity' (Newey, 2013: 111). Some of the gestures, such as pointed toes and extended hands, are shared by ballet and aerial performance. Leitzel deliberately chose to emphasise these gestures and to reference ballet by adopting positions that were directly comparable: thus, when she spun beneath her rings, her choice of alighting on pointed toes, and her costume (described in detail below). Not only that, but the form itself implies weightlessness through the use of momentum to achieve positions. Weight is pushed outwards in one direction and slows as gravity and momentum equalise, giving the impression of a brief pause. The most extreme example of this in Leitzel's act was the planche turn, 
during which her body appeared to both instigate actions and to be subject to jerky movements beyond her control. At the same time as she was described by the announcer as the only person capable of performing the feat, she was also considered by her contemporaries to 'whirl' free of effort. Although Søland primarily describes the Norwegian articulation of the modern girl, her identification of three key elements of a modern physical style is relevant for Anglo-American contexts: 'physical self-confidence, a graceful feminine body language, and a certain "natural" ease' (Søland, 2000: 56). Grace might initially be identified as a traditional attribute of femininity in the 1920 for its allusions to weightless femininity, but it instead holds a dual position that spoke to both modern and conservative audiences in slightly different ways.

What is interesting is that this reframing strategy was being used to some extent by young women of the day in order to make their challenging fashions more acceptable. For example, short bobbed haircuts risked censure for appearing masculine or mannish, but young women who aspired to be modern girls allayed these claims by reframing such fashions as different expressions of femininity. In the case of short hair, this was reinscribed as feminine by adopting wavy hairstyles that meant the style could be distanced from masculine short hair. It was the

clear stylistic differences between short hair for men and short hair for women [that] soothed critics, and gradually their opposition faded. With their confidence in the stability of sexual difference restored, some of the harshest opponents were even able to admit a few years later that they actually found short hair quite charming and attractive. (Søland, 2000: 40)

Read against this context, Leitzel's mixing of older and more modern expressions of femininity represents a similar negotiation of gender to that which young women were performing more widely. However, in Leitzel's case it allowed her to incorporate strength into her embodiment of femininity.

Leitzel's choice of being pulled into place by the property men is another example of reframing the modern as acceptable through elements considered traditional. This choice for her finale was a deliberate decision, because she had previously climbed up independently to reach her permanently rigged Roman rings. During the matinee performances when the tent was filled with light, these property men were visible and complicated her appearance of autonomy. At one moment she appeared subject to their action, yet at the same time these men would have 
appeared as no more than incidental subordinates carrying out a risky requirement of her act. It is interesting in the circus setting that the most conservative reading of this moment in her act was available during the matinee performances, while during the evening performances these men would probably have been invisible in the darkness. Even when a more modern reading is possible, where the property men are her subordinates, this is complicated by her 'regal' performance, making unusual use of her maid and footman and of publicity that designated her as circus 'aristocracy'. Analysing this further, a more 'modern' interpretation that allows for female agency and situates these men as her subordinates draws upon the authority of traditional social hierarchies to establish Leitzel's dominance within the circus.

Leitzel's choice to alight briefly before beginning the planche turns is a notable framing, as it demonstrates her modern self-confidence. In none of the reports of her contemporaries is there evidence of any other performer choosing to break up their short act (probably of around eight to ten minutes) into two such distinctive parts. Today this would also be an unusual choice in either traditional or corporate circus, where short acts are still performed as the norm..$^{20}$ Rather than being concerned that she might disrupt the pace of her act, Leitzel was sufficiently selfassured to consider that as the premier aerialist of her generation this would build anticipation for her signature trick. It also provided another opportunity to demonstrate her weightlessness as she sped towards the tent roof.

Such a modern attitude can also be seen in Leitzel's performance of enjoyment during the planche turns. Her performance style was very different to that of many of her contemporaries and to many aerialists working today. The experience of aerial performance is one where the convention is to hide pain as steel bars bruise limbs and ropes burn flesh. Feature articles devoted to Leitzel frequently emphasise the physical cost of her work, which included 'calluses ... water blisters', 'Rope burns' and 'raw ... hand[s]'. ${ }^{21}$ Memoir writers describe a constant sore created by the friction of the planche rope cuff against her skin (Kline, 2008: 208; Bradna and Spence, 1953: 150; Taylor, 1956: 218-19). Rather than masking the pain of her aerial movement with a blank face or slightly disconcerting fixed smile, Leitzel's wide smile instead demonstrated her pleasure in her body's aerial action. This contributed to the illusory sense that Leitzel was weightless through her hiding of the true effort and pain of her aerial action, but more importantly, it demonstrated her enjoyment in her body's movements - much as the modern 
girl reportedly demonstrated her fun-loving attitude when undertaking more moderate exercise.

There was, however, also something inescapably sexual about the visible effects of the planche turns on Leitzel's body that hints at her sexual agency. Fred Bradna considered Leitzel to have deliberately unpinned her hair for effect during her feat (Bradna and Spence, 1953: 150). Hair is frequently conflated with female sexuality, and Leitzel's unravelling locks during the planche turns emphasised her femininity. Leitzel's performance relied on her athletic ability and stamina. Her physical activity caused her heart rate and body temperature to rise and her breathing to become more pronounced. On alighting from the rope she had loose hair, she was breathing hard and she would have appeared flushed to those watching from the seats closest to the ring or stage. Not only did her appearance open her up to a reading of sexualisation through comparisons to a body that had orgasmed, it also demonstrated Leitzel appearing precisely in control of her own sexual(ised) physique. Audience members with a clear sight of Leitzel could arguably not have missed the sexual connotations and possible comparisons to a postcoital female body. The descriptions of Clara Bow and Louise Brooks above suggest that in film women were increasingly being represented as being in control of selecting their partner, while Barlow et al. consider women at large to have been claiming more control over when and if they married (Barlow et al., 2005: 288). It is likely that some members of the audience would have sexualised Leitzel's body without acknowledging her active role in the encounter, but I consider her performance to have deliberately emphasised her enjoyment of her aerial movements, whether they left her open to being sexualised or not.

\section{Dainty yet sexy costume}

The complex performance of femininity is also apparent in Leitzel's costume choices. Two very different costumes remain in the Tegge Circus Archives, and their survival dates them to the end of her career: the first appears similar - although not identical - to those Leitzel was photographed wearing for circus publicity, while the second is startlingly different. These two costumes indicate that Leitzel made very specific choices about how to expose her body in different performance settings. The way in which Leitzel managed her bodily exposure demonstrates how important presenting her gendered femininity was within her performance register. 
Photographs depicting Leitzel from around $1925^{22}$ and the circus costume (Figure 29) demonstrate how she combined her apparently contradictory daintiness with sexualised display. Her costume in 1925 highlights her female form: her breasts, the prime signifiers of the female body, are covered by two large triangles of fabric that stretch over her

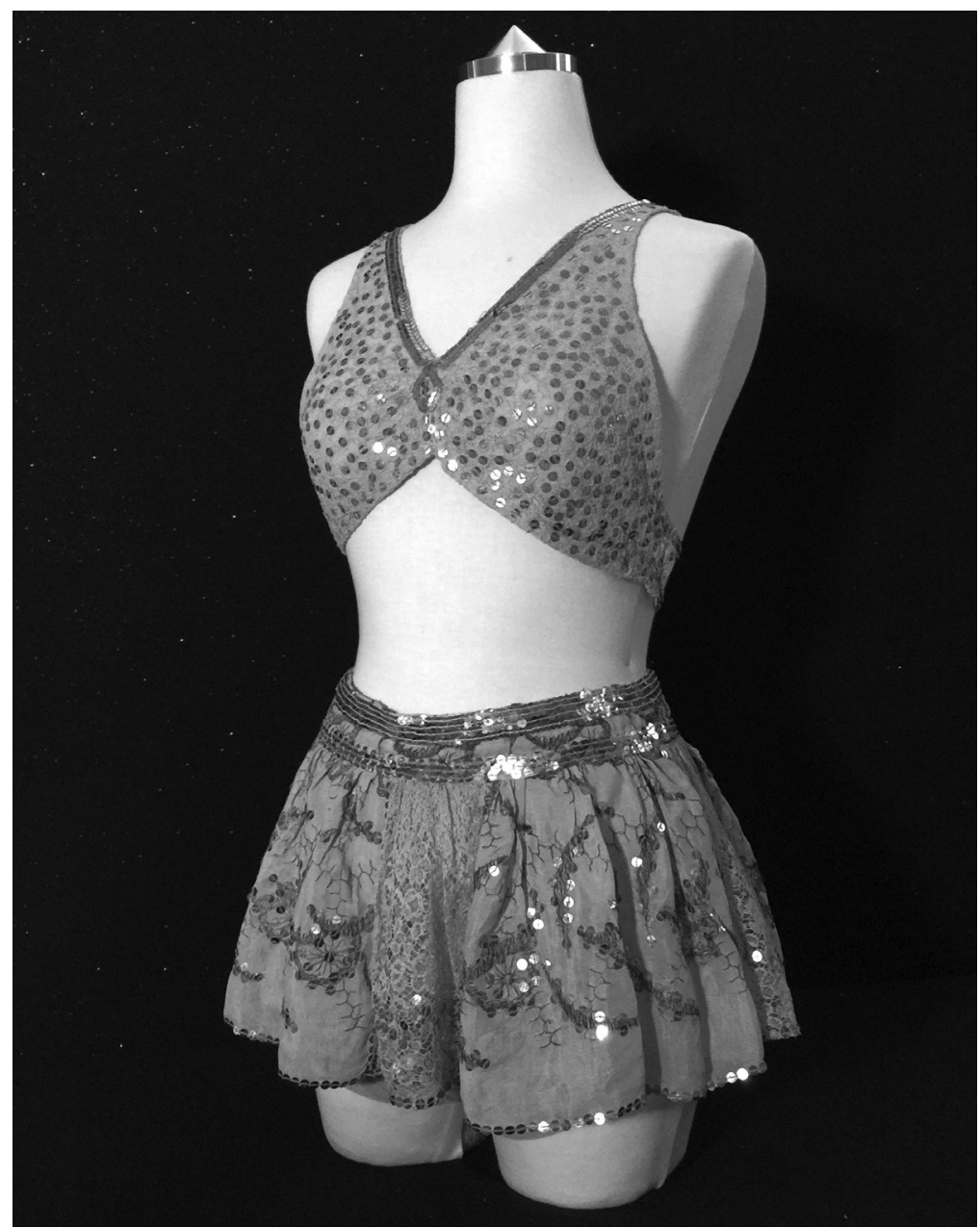

29 Lillian Leitzel's pink circus costume, $c$. 1925. From the collection of Timothy Noel Tegge/Tegge Circus Archives, Baraboo, WI,

Timothy Tegge. 
shoulders; her small waist is accentuated by a band that encircles it and includes the traditional feminine accessory of a flower; the skirt evokes a ballet tutu as light, chiffon-like fabric cascades and pleats over her hips; the shortness of the skirt exposes short trunks that elongate the apparent length of legs clothed in silk stockings; her feet are covered by shoes that also bear comparison to ballet shoes. Examination of both earlier and later photographs of Leitzel and the circus costume in the archive indicate that Leitzel's ballet-like skirt emerged around 1920 and remained a feature of her costume until her death in $1931{ }^{23}$ This was a costume that sought to draw upon more conservative ideals of femininity through the references to ballet, the flower accessory and her choice of wearing long hair rather than cutting it fashionably short. It is these conservative elements that give an impression of daintiness, and even make the diminutive Leitzel appear almost doll-like. Yet there is clearly something modern in exposing arms and dressing legs in fashionable silk stockings. Like the act itself, her costume negotiated gender in a complex manner, presenting her body as conventionally dainty at the same time as it was sexualised by exposure.

Although the overriding impression of Leitzel's costume may have been one of girlishness, there is a sexualised tension related to the amount of flesh exposed. The shortness of Leitzel's skirt sexualised her body, exposing more leg than even the modern girl may have considered acceptable. The later circus costume demonstrates how Leitzel managed and developed this exposure throughout her career (Figure 29). This light pink costume is made of two parts linked at the back by faded and degraded elastic: the top half is formed of two triangles that would have covered her breasts but exposed her midriff; and again the bottom half is a combination of short trunks covered by a skirt which is this time much briefer. Sequins are sewn into both top and bottom, but most densely congregate around the waistband and the triangles that cover the breasts. The sides of the skirt are made of light fabric, but the central panel and the trunks underneath it are made of lace-like material that hints at exposing the body. Costume is separate from everyday wear and is acceptable provided that exposure fits within the conventions of the particular performance space. It was a safety requirement for aerialists to wear clothing that closely fitted arms and legs, or else exposed them. However, Leitzel went far beyond the normal conventions of circus costuming, and by the end of the 1920 s was pioneering in the exposure of her midriff: her circus costume is designed to expose, as much as clothe, her body. 


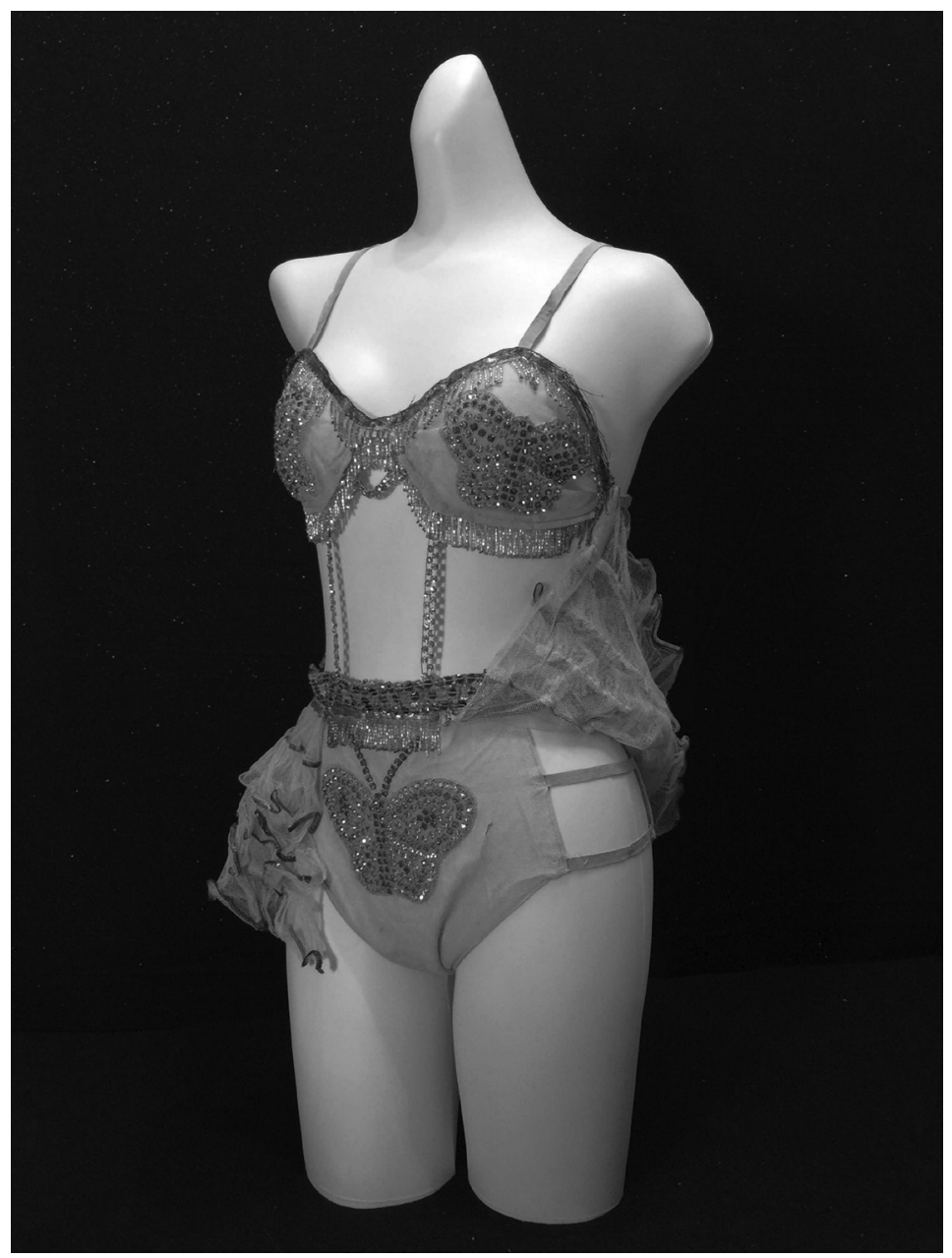

30 Lillian Leitzel's vaudeville costume, late 1920s. From the collection of Timothy Noel Tegge/Tegge Circus Archives, Baraboo, WI, Timothy Tegge.

The circus was not the only performance space in which Leitzel exposed most of her strong body. The second costume in the archive is strikingly brief and unlike any that I have seen her photographed wearing: it resembles less a short dress and more a bikini (Figure 30). Even if age has degraded the elastic that holds the top in place, it still does 
not seem strong enough for the costume to have retained its position during her violent planche turns, suggesting that a body stocking must have been worn underneath. Regardless, Leitzel's body would have been startlingly on display, with her sex emphasised due to the positioning of the glittering butterflies over breasts and in the proximity of the crotch. The slight ruffles of fabric at the hips evoke the circus ballet skirt but were designed to expose bare hips when her body was inverted. This is clearly a costume that sells sex more overtly within another performance context. The most likely answer is that this costume was one Leitzel used in vaudeville or variety spaces where she would have appeared alongside the 1920s showgirls and chorus girls who exposed more of their bodies than in the circus (Latham, 2000: 109). In the context of vaudeville's more significant exposure, Leitzel made the decision to make her body appear closer to nudity in order to succeed.

What makes this exposure unusual is the body that was exposed and presented as desirable. Aerial practices such as Leitzel's require a strong upper body that leads to increased muscle mass. Although Leitzel was always described as feminine, her developed upper body was compared to that of a 'middle-weight boxer' or 'professional wrestler' (Verney, 1978: 202; Butler, quoted in Taylor, 1956: 219). Not only does this depict her body as muscular, it also indicates that such muscularity was associated with masculinity, as boxers and wrestlers were almost exclusively male professionals in the 1920s. Here the tension regarding sex, exposure and agency becomes apparent: Leitzel deliberately positioned her body as a sexual object in order to perform sexual agency - much in the same way that modern girls were exposing their limbs in fashion-wear as well as claiming more sexual choice for themselves. What is radical here, perhaps, is that this woman enjoyed her strength and muscularity and deliberately chose to sexualise her body via its unusual muscle mass. Leitzel's significant bodily exposure was a matter of pride; she gloried in her muscle in the moment of performance rather than hiding it from view - positioning a muscular female body as desirable within a mainstream popular entertainment.

\section{Agency and performance style}

It may seem quite a bold statement to claim that Leitzel was positioning herself as having sexual agency through her bodily exposure, when a simplistic reading would position her as a passive sexualised object under the control of a desiring gaze. However, Leitzel's performance of 
femininity was always a series of contradictions: she presented herself as conservative yet challengingly modern, dainty yet unabashedly sexual. As with so much surrounding Leitzel, the key to understanding the paradox is to consider how the act was framed or performed. In performing the public face and unconventional body of Lillian Leitzel, she performed herself as being in control. Not only was she in control of the sexualised encounter, her control had the power to disrupt the circus itself, without Leitzel suffering any future consequences other than an increase in popularity.

The fullest written accounts of Leitzel's act appear in memoirs, and when subjected to analysis these inevitably highlight these contradictions in her performance persona. Robert Lewis Taylor's description of the opening moments of her act highlights how daintiness and sexual and professional power coexisted within her sophisticated performance of femininity. It is worth quoting at length here.

The house lights faded, a single spot played over the arena, then caught her up, as if by surprise, at the entrance. When she walked or was carried into the center ring, the snare drums accompanied her in a long roll and a cymbal crashed as she finally bowed, very slightly, as royalty might incline the head. The star herself was usually costumed in a sequined brassière, with a bare midriff, and over them a short, sheer skirt. Altogether, Miss [Jennie] Rooney [an aerial colleague of Leitzel's] says, the effect was sexy ... It was at this point of entrance that Miss Leitzel was supposed to throw off an ankle-length cape she wore in, kick aside a pair of gold-colored mules, and buckle down to work. But she seldom did, and therein lay a rub, for a circus performance runs on a kind of rail-road-tight schedule. She savored and tasted her power. She stood at ease and looked around, establishing the wonderfully electric connection between herself and her audience. She would giggle slightly, and people would break into roars of sympathetic laughter. With an arch look that seemed to mean, Miss Rooney felt, 'I've noticed you in particular; anything can happen,' she would kick-off her mules slowly, as if in a prelude to something intensely personal, and men, quite literally, often started down out of the stands. (Taylor, 1956: 221)

Taylor's writing style is somewhat extravagant, but what is particularly fascinating about this excerpt is the way in which 'girlish' attributes, sexualised display and sexual power are all identified. Leitzel giggles girlishly and is sometimes carried into the ring; the effect of her bodily exposure is sexual, but she is in control of the sexualised encounter because she chooses her mate. In fact, Jennie Rooney's statement that Leitzel's 
look meant 'anything can happen' suggests that she expected to be a key instigator rather than a subordinate in any sexual activity. Replace Leitzel for a moment with Louise Brooks or Clara Bow and the sexual assertiveness and choosing of a partner would perhaps be appropriate. Leitzel may have appeared dainty, but her performed assertive sexual agency cannot be in doubt.

It is also interesting that Taylor remarks on Leitzel's power and that he identifies this as related to sexual agency, her electric connection to her audience and her ability to disrupt the circus schedule. This performance of femininity included within it strong elements of modern self-assurance, which might also be considered an attribute of good performance technique, and is precisely what allowed her to represent herself as being in control of the circus. The American Ringling Bros and Barnum \& Bailey management themselves had accorded Leitzel the prestige and honour of having action stopped in all other rings and on all other stages during her performance. This allowed her performance of control to appear unchallenged by any other action. Taylor reports moments, other than during her entry, when Leitzel would deliberately extend the duration of her act, describing how she would 'rock gently back and forth for several minutes, smiling, [and] waving [at the top of the rope she used to climb up to her rings] ... The audience was delighted and encouraged her to disrupt the show as long as she pleased' (Taylor, 1956: 216). By performing the assertive role of diva, Leitzel demonstrated the agency that her glamorous celebrity conferred. The Ringling-Barnum circus emphasised the logistics required to transport a circus of its scale in publicity, and a few extra minutes of performance would have delayed the striking of the Big Top and movement on to the next city. Against this context, Leitzel's disruptive power is significant and evidences the ways in which she could publicly disrupt the entire circus logistics itself. The fact that Taylor treats this as commonplace indicates that there were no adverse consequences for Leitzel. This performance of female power was central to her success - as circus 'royalty' Leitzel could do what she pleased, provided her audience were 'delighted' by the disruption.

Leitzel's act and the way in which she performed her femininity was remarkable. The planche turns performed as an endurance act, in particular, were an extreme feat of strength with or without any gendered framing. The way in which Leitzel performed her femininity by reference to its various expressions designated her personality as feminine, reframing the planche turn finale as a remarkable feminine demonstration 
of strength. The planche turns may have represented an exhibition of 'masculine' strength and endurance, but Leitzel also performed her complex femininity through them - challenging a reading that gendered them as purely masculine. This argument explains how Leitzel turned an act of strength into part of the female repertoire, with women famously copying Leitzel's trademark planche turns in the latter years of her career and soon after her death - Mickey King, Irma Ward and Janet May (Kline, 2008: 213).

Leitzel was, however, the only performer who could, and did, choose to challenge circus management through her refusal to consider circus logistics before the success of her own act. The paradox was that in order to get away with such disruptive acts she needed to be the most popular circus star, yet her popularity relied on such performances of power. In the moment of performance Leitzel positioned herself as having choice over whether to disrupt the entire Ringling-Barnum circus. Lillian Leitzel was the Queen of the Circus in part because she performed such complex representations of femininity. Her success and that of her female soloist colleagues relied on the balancing act they performed between reflecting progressive modern stereotypes of femininity, while including just enough conservative allusions that modern and traditionalist readings could coexist and, in some cases, even be challenged. Through her extraordinary physical abilities, Leitzel's dainty yet agencyinfused performances of female sexuality were cultural contradictions on which her success relied - her act expressing and reflecting cultural anxieties surrounding changing stereotypes of femininity, as well as feeding on a public fascination with physical feats. Solo female aerialists as a whole were performing similar acts of gender negotiation as those of modern girls within wider society, by presenting muscular bodies as feminine and glamorous. Female aerial soloists were public figures who popularised strong and active female bodies within mainstream culture. Today we may have some reservations about Leitzel's decision to use the tool of sexual desirability within a patriarchal system. However, through this strategy she claimed a more dominant role for herself by performing female agency at a time when this was still controversial, and by her publicised control over her professional career. Not only that, by appearing as a sexually desirable and muscular woman in the mainstream entertainments of circus, vaudeville and variety, she almost certainly contributed to physical strength becoming more acceptable as a form of performed femininity. 


\section{Notes}

1 Those notable exceptions who designate aerialists as stars, such as Helen Stoddart (2000: 56-7) and Peta Tait (2005, 2007), do not, however, explore issues of stardom.

2 For a detailed discussion of how representations of women were restricted by censorship in the early twentieth century, see de Jongh (2001: 35-81).

3 Alfredo Codona, correspondence with Billy Adolph, 4 January 1926, Codona Family Collection, Tegge Circus Archives, p. 1.

4 The origin of this title is hard to ascertain, as 'Queen' is used by performers and management alike to describe Leitzel in their memoirs, as well as in press and publicity placed by the Ringling-Barnum circus, obscuring the origin of the accolade (Kline, 2008: 208; North and Hatch, 2008; 'Circus Has Own Aristocracy - Marriage of Lillian Leitzel and Clyde Ingalls Reveals Rigid Rules in the Sawdust Ring Profession', 7 February 1920, T-CLP Leitzel, Lillian, Billy Rose Collection, New York Public Library).

5 Robert L. Parkinson, research note, 1971, CWM Small Collections, Leitzel, Lillian - letters and other documents, Circus World Museum, Baraboo, Wisconsin.

6 Alfred Pelikan, correspondence with Karl Kae Knecht, 20 February 1931, CWM Small Collections, Leitzel, Lillian - letters and other documents, Circus World Museum, Baraboo, Wisconsin.

7 Ringling Brothers, Artists's Contract and Release with Lillian Leitzel, 11 October 1916, CW Employment Contracts, Ringling Brothers Small Collections Box 2; Ringling Bros and Barnum \& Bailey, Ringling Bros and Barnum and Bailey Combined Shows The Greatest Show on Earth Daily Review Magazine, 1927, tenting/road edition, CWM Mss3, Circus World Museum, Baraboo, Wisconsin.

8 Leitzel fell at the Valencia Music Hall in Copenhagen when one of the swivels of her Roman rings snapped as she was coming out of a handstand. She died in hospital a few days later, on 15 February 1931. Maud Clemings, correspondence with Fred and Melba Pelikan, 15 February 1931, CWM Small Collections, Leitzel, Lillian - letters and other documents, Circus World Museum, Baraboo, Wisconsin.

9 For more on my argument about how risk and skill contributed to aerial celebrity and were gendered in the 1920 s and early 1930s, see Holmes (2016: 124-54).

10 'Olympia Circus - Presentation to Captain Bertram Mills', The Times, 20 January 1922, p. 7.

11 'Governor Sips Punch with Performers and Other Dignitaries', no date, Lorabel Laughlin Richardson's scrapbook, Tegge Circus Archives.

12 See film of Lillian Leitzel's act, no date, Codona home videos, Tegge Circus Archives. 
13 Ibid.

14 Dan DeBaugh, Dan DeBaugh Presents The World's Largest Circus in Action: Ringling Bros and Barnum \& Bailey in the Nineteen-Twenties, 1928-33, and film of Lillian Leitzel's act, no date, Codona home videos, Tegge Circus Archives.

15 Planche refers to a whole series of moves that rely on the body appearing straight despite the effort of gravity - it means 'board' in French. The climbs described earlier as mainly performed by men are actually a type of planche climb. The planche rope is a type of rope that allows the planche turns to be completed and is only used for this trick. People performing this trick today would probably only do one or two as part of a wider act on rope or straps.

16 P. H. Paulinetti, 'The World's Greatest Gymnast', Strength - The Magazine of Good Health, April 1923, p. 41, Tegge Circus Archives; DeBaugh, Dan DeBaugh Presents The World's Largest Circus in Action; and film of Lillian Leitzel's act, no date, Codona home videos, Tegge Circus Archives.

17 'The Star Act', Harrisburg Patriot, 27 June 1911, p. 10.

18 See the photograph by Harry Atwell of Lillian Leitzel performing a one-arm planche, CWi 1031, glass plate negative, 1930, Circus World Museum, Baraboo, Wisconsin.

19 C. E. Williams, 'Strength is Life Says Lillian Leitzel, Circus Queen', Physical Culture, July 1923, p. 92, Steve Wennestrom Collection, SW-Bx6F52, HJ Lutcher Stark Center for Physical Culture and Sports.

20 This is not true of contemporary circus because performances are generally longer in duration. Rather than existing as separate acts, contemporary circus seeks to unify the performance through a theme or narrative. It might best be imagined as a combination of traditional circus and physical theatre and less frequently, live art.

21 Basil Queed, 'How'd You Like To Be In My Place? Leitzel, the Circus Queen, Tells Why She Longs to Be a Typist', Liberty, 5 June 1926, p. 51, CWM Small Collections, Leitzel, Lillian, clippings, Circus World Museum, Baraboo, Wisconsin.

22 Although listed as taken in 1928 by Circus World Museum, I date these images to around 1925 (including Figure 28). The series of black-and-white images taken by Harry Atwell show Leitzel in the same white or lightcoloured costume, suggesting that they were taken during the same shoot. One of the images appears edited in the 1925 New York Ringling Bros and Barnum and Bailey Combined Shows The Greatest Show on Earth Daily Review Magazine.

23 See also Daguerre, photograph of Lillian Leitzel telling off a doll, 1920, Lillian Leitzel portraits $8 \times 10$, CWM Small Collections, Circus World Museum, Baraboo, Wisconsin. 


\section{References}

Barlow, Tani E., Madeleine Yue Dong, Uta G. Poiger, Priti Ramamurthy, Lynn M. Thomas and Eve Alys Weinbaum (2005), 'The Modern Girl around the World: A Research Agenda and Preliminary Findings', Gender and History, 17.2, pp. 245-94.

Bradna, Fred, and Hartzell Spence (1953), The Big Top: My Forty Years with the Greatest Show on Earth, London: Hamish Hamilton.

Croft-Cooke, Rupert, and W. S. Meadmore (1946), The Sawdust Ring, Watford: Odhams Press.

Dahlinger Jr, Fred (2008), 'Afterword', in Henry Ringling North and Arlen Hatch, The Circus Kings - Our Ringling Family Story, Gainesville, FL: University Press of Florida, pp. 384-40o.

Davis, Janet M. (2002), Circus Age: Culture and Society under the American Big Top, Chapel Hill, NC: University of North Carolina Press.

De Jongh, Nicholas (2001), Politics, Prudery and Perversions - The Censoring of the English Stage 1901-1968, London: Methuen.

Holmes, C. J. (2016), 'Aerial Stars: Femininity, Celebrity and Glamour in the Representations of Female Aerialists in the UK and USA in the 1920 s and Early 1930s', PhD thesis, University of Exeter.

Kingsley Kent, Susan (2009), Aftershocks. Politics and Trauma in Britain, 19181931, Basingstoke: Palgrave Macmillan.

Kline, Tiny (2008), Circus Queen \& Tinker Bell - the Memoir of Tiny Kline, ed. Janet M. Davis, Urbana, IL: University of Illinois Press.

Landay, Lori (2002), 'The Flapper Film: Comedy, Dance, and Jazz Age Kinaesthetics', in Diane Negra and Jennifer M. Bean, eds, A Feminist Reader in Early Cinema, Durham, NC: Duke University Press, pp. 221-48.

Latham, Angela J. (200o), Posing a Threat: Flappers, Chorus Girls, and Other Brazen Performers of the American 1920s, Middletown, CT: Wesleyan University Press.

Manning-Sanders, Ruth (1952), The English Circus, London: T. Werner Laurie.

Melman, Billie (1988), Women and the Popular Imagination in the Twenties: Flappers and Nymphs, Basingstoke: Palgrave Macmillan.

Newey, Katherine (2013), 'Fairies and Sylphs: Femininity, Technology and Technique', in Kara Reilly, ed., Theatre, Performance and Analogue Technology, Basingstoke: Palgrave Macmillan, pp. 97-116.

North, Henry Ringling, and Arlen Hatch (2008), The Circus Kings - Our Ringling Family Story, Gainesville, FL: University Press of Florida.

O’Brien, Esse Forrester (1959), Circus Cinders to Sawdust, San Antonio, TX: The Naylor Company.

Pond, Irving K. (1948), 'The Lovely Leitzel', in Rupert Croft-Cooke, ed., The Circus Book, London: Sampson Low, pp. 123-5.

Skillen, Fiona (2012), “Woman and the Sport Fetish”: Modernity, Consumerism 
and Sports Participation in Inter-war Britain', The International Journal of the History of Sport, 29.5, pp. 750-65, http://dx.doi.org/10.108o/09523367.2012.67 5206.

Skillen, Fiona (2013), Women, Sport and Modernity in Interwar Britain, Bern: Peter Lang.

Søland, Brigitte (200o), Becoming Modern: Young Women and the the Reconstruction of Womanhood in the 1920s, Princeton, NJ: Princeton University Press.

Stoddart, Helen (2000), Rings of Desire: Circus History and Representation, Manchester: Manchester University Press.

Studwell, William Emmett, Charles P. Conrad and Bruce R. Schueneman (1999), Circus Songs: An Annotated Anthology, London: Haworth Press.

Tait, Peta (2005), Circus Bodies: Cultural Identity in Aerial Performance, London: Routledge.

Tait, Peta (2007), 'Circus Performers as Action Hero: Codona and Leitzel', in Robert Sugarman, ed., The Many Worlds of Circus, Newcastle: Cambridge Scholars Publishing, pp. 37-45.

Taylor, Robert Lewis (1956), Center Ring: The People of the Circus, New York: Doubleday.

Verney, Peter (1978), Here Comes the Circus, London: Paddington Press.

Williamson, A. Stanley (1938), On the Road with Bertram Mills, London: Chatto and Windus.

Zweiniger-Bargielowska, I. (2011), 'The Making of a Modern Female Body: Beauty, Health and Fitness in Interwar Britain', Women's History Review, 20.2, pp. 299-317.

\section{Archives}

\section{Circus World Museum, Baraboo, Wisconsin}

Harry Atwell, Lillian Leitzel performing a one-arm planche, CWi 1031, glass plate negative, 1930

Maud Clemings, correspondence with Fred and Melba Pelikan, 15 February 1931, CWM Small Collections, Leitzel, Lillian - letters and other documents

Daguerre, photograph of Lillian Leitzel telling off a doll, 1920, Lillian Leitzel portraits $8 \times 10$, CWM Small Collections

Robert L. Parkinson, research note, 1971, CWM Small Collections, Leitzel, Lillian - letters and other documents

Alfred Pelikan, correspondence with Karl Kae Knecht, 20 February 1931, CWM Small Collections, Leitzel, Lillian - letters and other documents

Basil Queed, 'How'd You Like To Be In My Place? Leitzel, the Circus Queen, Tells Why She Longs to Be a Typist', Liberty, 5 June 1926, pp. 49-52, CWM Small Collections, Leitzel, Lillian, clippings

Ringling Brothers, Artists's Contract and Release with Lillian Leitzel, 11 
October 1916, CW Employment Contracts, Ringling Brothers Small Collections Box 2

Ringling Bros and Barnum \& Bailey, Ringling Bros and Barnum and Bailey Combined Shows The Greatest Show on Earth Daily Review Magazine, 1925, New York (Madison Square Garden) edition, CWM Mss3

Ringling Bros and Barnum \& Bailey, Ringling Bros and Barnum and Bailey Combined Shows The Greatest Show on Earth Daily Review Magazine, 1927, tenting/road edition, CWM Mss3

HJ Lutcher Stark Center for Physical Culture and Sports, University of Texas, Austin

C. E. Williams, 'Strength is Life Says Lillian Leitzel, Circus Queen', Physical Culture, July 1923, pp. 29-32, 92-3, Steve Wennestrom Collection, SW-Bx6F52

New York Public Library

'Circus Has Own Aristocracy - Marriage of Lillian Leitzel and Clyde Ingalls Reveals Rigid Rules in the Sawdust Ring Profession', 7 February 1920, T-CLP Leitzel, Lillian, Billy Rose Collection

Tegge Circus Archives, Baraboo, Wisconsin, http://www.teggecircusarchives.org

Alfredo Codona, correspondence with Billy Adolph, 4 January 1926, Codona Family Collection

DeBaugh, Dan, Dan DeBaugh Presents The World's Largest Circus in Action: Ringling Bros and Barnum \& Bailey in the Nineteen-Twenties, 1928-33, film

Film of Lillian Leitzel's act and behind the scenes, no date, Codona home videos 'Governor Sips Punch with Performers and Other Dignitaries', no date, Lorabel Laughlin Richardson's scrapbook

P. H. Paulinetti, 'The World's Greatest Gymnast', Strength - The Magazine of Good Health, April 1923, front cover and pp. 30, 37-42, 74 